\title{
Menjadi Perempuan Tambak Lorok: Konstruksi Gaya Hidup Perempuan Muslim Pesisir
}

\author{
Ririh Megah Safitri \\ Fakultas Ilmu Sosial dan Ilmu Politik Universitas Islam Negeri Walisongo, Semarang \\ (e-mail: ririh.megah.safitri@walisongo.ac.id)
}

\begin{abstract}
Identity and existence become a crucial issue lately, both in the factual context even cyberspace (cyber society). In this context lifestyle construction is the main issue to analysis the coastal Muslim women's identity. The study of the lifestyle construction of coastal Muslim women uses qualitative methodologies to obtain a comprehensive meaning regarding lifestyle. There are several influential factors in the process of forming individual lifestyles. The first one is the cultural, social and religious background that has been internalized in each individual through cultural values and social norms. The second factor is the environment where individuals live and socialize with the other society. In this context, the physical elements which include geographical, topographic and climate appearance are the main influences on the construction of individual lifestyles related to the adaptation process. Another influential factor is the media that the content is a lifestyle preference. Based on these factors, this study will focus on three points, there is the perception of coastal women on lifestyle, factors that influence the process of lifestyle construction and the meaning of coastal Muslim women's lifestyle. There are three conclusions in this study regarding the hidden goals in consumption activities refer to saving material, representation of social status through lifestyle and indicators of self-existence.
\end{abstract}

Identitas dan eksistensi menjadi isu krusial belakangan ini, baik dalam konteks faktual kemasyarakatan maupun dalam dunia maya. Dalam konteks ini konstruksi gaya hidup menjadi isu utama untuk menganalisis identitas perempuan Muslim pesisir. Studi tentang konstruksi gaya hidup wanita Muslim pesisir ini menggunakan metodologi kualitatif untuk mendapatkan pemaknaan yang komprehensif tentang gaya hidup. Ada beberapa faktor yang berpengaruh dalam proses pembentukan gaya hidup individu. Pertama adalah latar belakang budaya, sosial dan agama yang telah diinternalisasi pada setiap individu melalui nilai-nilai budaya dan norma sosial. Faktor kedua adalah lingkungan tempat individu hidup dan bersosialisasi dengan masyarakat lain. Dalam konteks ini, unsur fisik yang meliputi penampilan geografis, topografi, dan iklim adalah faktor utama yang berpengaruh pada konstruksi gaya hidup individu yang terkait dengan proses adaptasi. Faktor lain yang berpengaruh adalah media sebagai preferensi gaya hidup. Berdasar pada faktor tersebut, maka kajian ini akan berfokus pada tiga point yakni persepsi perempuan pesisir atas gaya hidup, faktor yang berpengaruh pada proses konstruksi gaya hidup dan makna yang ingin disampaikan perempuan Muslim pesisir melalui gaya hidupnya. Terdapat tiga simpulan utama dalam kajian ini terkait hidden goals dalam kegiatan konsumsi yakni saving material, representasi status sosial melalui gaya hidup dan indikator eksistensi diri.

Keywords: lifestyle; coastal women; religion 


\section{Pendahuluan}

Identitas dan eksistensi diri menjadi isu yang krusial belakangan ini, baik dalam konteks kemasyarakatan pun dalam konteks dunia maya. Setiap orang berlomba-lomba mengkonstruksi identitasnya demi mencapai sebuah eksistensi atas dirinya. Faktanya pengakuan atas eksistensi atau kehadiran diri menjadi goals list yang dituju setiap orang. Salah satu fakta yang menunjukkan kondisi tersebut yakni Indonesia menjadi salah satu negara dengan jumlah pengguna internet tinggi pada tahun 2016 berkisar 88,1 juta orang berdasar pada hasil survey lembaga marketing sosial Singapura yakni We Are Social (Muhamad 2016). Data tersebut membuat Indonesia menjadi negara pengguna internet dan media sosial tertinggi di ASEAN. Pada konteks ini cara atau strategi yang digunakan setiap orang akan berbeda-beda, seperti melalui aspek ekonomi (stratifikasi sosial), aspek pendidikan, aspek mata pencaharian (profesi), aspek gaya hidup dan aspek yang lainnya. Pada konteks kajian ini konstruksi gaya hidup menjadi isu utama yang akan diteliti lebih jauh lagi. Hal tersebut dikarenakan gaya hidup menjadi salah satu indikator yang nampak atau terlihat secara fisik Sehingga akan lebih mudah mengidentifikasi identitas individu melalui kenampakan gaya hidupnya.

Gaya hidup bukanlah identitas yang dapat dibentuk dalam proses yang singkat. Namun gaya hidup merupakan sebuah proses identifikasi yang dilakukan berulang-ulang oleh individu. Dengan demikian identifikasi merupakan proses yang dinamis dan berlangsung secara kontinu. Begitupula dengan gaya hidup yang merupakan sebuah proses dinamis dan berlangsung secara kontinu selama individu tersebut masih hidup. Oleh karena itu setiap individu akan memiliki gaya hidup yang berbeda satu dengan yang lain. Isu terkait konsumsi dan gaya hidup telah menjadi isu sentral dalam perkembangan masa belakangan ini. Oleh karena itu, berbagai dinamika yang muncul terkait dengan isu konsumsi dan gaya hidup suatu masyarakat patut untuk dikaji lebih dalam. Pentingnya mengkaji gaya hidup yang dimiliki oleh masyarakat sejalan dengan teori konstruksi gaya hidup milik Chaney, "gaya hidup kita membantu mendefinisikan sikap, nilai-nilai, dan menunjukkan kekayaan serta posisi sosial kita" (Chaney 2011). Gaya hidup lantas tidak hanya sebagai sebuah upaya memenuhi berbagai kebutuhan biologis saja namun juga memenuhi kebutuhan 'sosial' individu dalam bermasyarakat. Konstruksi gaya hidup masyarakat Muslim pesisir di Tambak Lorok Semarang dengan karakteristik masyarakatnya akan menjadi objek utama kajian ini.

Terdapat beberapa faktor yang turut berpengaruh dalam proses pembentukan gaya hidup individu. Pertama yakni budaya atau latar belakang etnis yang dimiliki oleh individu (Rizqi, Suminto, and Ermawati 2017). Kajian Rizqi et al. (2017) terkait "Potret Perempuan Dayak Iban, Kayan, Desa dan Sungkung di Kalimantan Barat" menunjukkan bahwa masyarakat Dayak memiliki norma, ketentuan, dan peraturan-peraturan yang dipatuhi bersama sebagai suatu ikatan sehingga melahirkan sebuah identitas pada Suku Dayak. Pada konteks ini perwujudan norma, ketentuan dan peraturan tersebut tidak dimaksudkan untuk 
membatasi namun justru memuliakan perempuan Dayak dalam kesehariannya. Pengaruh norma, ketentuan, peraturan dan situasi alam tercermin dalam sikap dan gaya hidup perempuan Dayak seperti menggambar tato ditubuh, tradisi memanjangkan daun telinga, pengenaan gelang kuningan, tenun serta anyaman (Rizqi et al. 2017).

Nilai kultural dan norma sosial yang telah terinternalisasi pada setiap diri individu akan dijadikan sebagai pedoman dalam setiap aktivitas yang dilakukan oleh individu tersebut. Dengan kata lain, individu akan melakukan apa yang disarankan dalam nilai kultural dan norma sosial begitupun sebaliknya, individu akan menjauhi hal-hal yang turut diatur dalam sistem nilai dan norma yang diyakini dalam sebuah masyarakat. Internalisasi nilai kultural dan norma sosial nampak dalam pola asuh anak sedari kecil. Pada konteks ini anak akan diajari bagaimana harus bersikap dan menjalankan kehidupan sesuai dengan ideal value yang diyakini bersama. Dalam konsep ideal value tersebut akan terlihat pula persepsi masyarakat atas eksistensi individu yang merujuk pada indikator-indikator yang digunakan masyarakat untuk melegitimasi eksistensi atas individu. Masyarakat pesisir Tambak Lorok masuk dalam wilayah administratif Kota Semarang, sehingga secara geografis masyarakat pesisir Tambak Lorok berlatarbelakang etnis Jawa. Namun terdapat kekhasan yang dimiliki oleh masyarakat Tambak Lorok karena tinggal di wilayah pesisir. Kekhasan tersebut merujuk pada tradisi yang dimiliki oleh masyarakat pesisir, sehingga meskipun berlatarbelakang etnis Jawa namun memiliki karakteristik tersendiri sebagai masyarakat pesisir.

Faktor yang kedua yakni lingkungan sekitar dimana individu hidup, tinggal dan bersosialisasi dengan individu yang lain (Sumar dan Karman 2014). Pada konteks ini unsur fisik yang meliputi kenampakan geografis, topografis dan iklim menjadi pengaruh utama atas konstruksi gaya hidup individu. Proses adaptasi yang dilakukan individu untuk bertahan hidup di lokasi tersebut menjadi praktik identifikasi yang akan berujung pada sebuah pola hidup dan gaya hidup. Seorang individu akan menghabiskan waktunya di lingkungan tempat tinggalnya, dengan demikian individu tersebut harus memiliki peta sosial atas lingkungannya. Kajian Sumar dan Karman (2014) yang berjudul "Perempuan Berjilbab: dari Identitas hingga Tren Mode Pasca Konflik di Maluku Utara" menunjukkan adanya pergeseran gaya hidup yang ditunjukkan oleh perempuan sebagai hasil dari proses adaptasi terhadap lingkungan konflik dan pasca konflik. Konflik horisontal yang terjadi di Maluku Utara yang melebar menjadi konflik antar agama tersebut praktis membuat masyarakat yang tinggal di Maluku Utara mempertegas identitas keagamaan masing-masing, termasuk perempuan. Situasi dan kondisi tersebut berbanding terbalik dengan suasana sebelum konflik, mengingat Maluku Utara menjadi daerah destinasi migran sehingga masyarakat Maluku Utara merupakan masyarakat yang heterogen baik latar belakang suku maupun agamanya. Pada konteks pasca konflik, batas agama yang 
sangat mencolok terlihat pada perempuan Muslim yang mulai mengenakan jilbab secara massal. Model jilbab yang dipakai disesuaikan dengan situasi dan kondisi lingkungan, oleh karena itu model jilbab dan cara mengenakannya pun biasa saja. Selain itu jilbab yang dikenakan berupa sepotong kain dengan ukuran tertentu dilipat melingkar sehingga menutupi sebagian wajah dan dagu. Mengingat pada saat itu hanya terdapat dua toko busana Muslim di Maluku Utara (Sumar dan Karman 2014).

Pengetahuan tentang karakteristik lingkungan sangat diperlukan guna mendukung semua aktivitas yang dilakukannya. Termasuk untuk memposisikan dirinya dalam konteks kemasyarakatan. Seperti halnya yang terjadi pada masyarakat pesisir Tambak Lorok. Lokasi tempat tinggalnya di pesisir pantai utara membuat sebagian besar masyarakatnya berprofesi sebagai nelayan dan pedagang ikan (hasil nelayan). Tinggal di lokasi pesisir pasti akan berbeda dengan individu yang tinggal di lokasi non pesisir, dimulai dari ketersediaan air, topografi tanah hingga pada peta sosial masyarakat (sistem penataan dan pengelolaan kampung dan desa). Kondisi tersebut praktis akan berpengaruh pada proses identifikasi dan konstruksi gaya hidup masyarakatnya. Seperti yang sudah saya sampaikan pada bagian sebelumnya bahwa proses adaptasi yang dilakukan masyarakat sebenarnya juga merupakan proses konstruksi gaya hidup. Hal tersebut merujuk pada bagaimana masyarakat hidup dengan menyesuaikan karakteristik wilayah tempat tinggalnya.
Faktor lain yang turut berpengaruh pada konstruksi gaya hidup adalah media (Abdullah 2001, 2006; Featherstone 1997; Hendariningrum and Susilo 2008; Rofhani 2017; Sugiharti 2014). Kajian Rofhani (2017) terkait "Ekspresi dan Representasi Budaya Perempuan Muslim Kelas Menengah di Surabaya" menunjukkan bahwa konten islami dalam media khususnya model busana islami telah melahirkan kelas menengah baru di Surabaya. Perempuan Muslim yang termasuk dalam kelas menengah baru tersebut telah bernegosiasi dengan nilai dan kultur islam dalam mengekspresikan identitas melalui pemakaian turban, jilbab, baju serta inovasi warna terbaru. Praktis gaya yang ditampilkan kemudian berbeda dengan gaya penampilan normatif perempuan Muslim lainnya. Rofhani melihat kondisi tersebut sebagai identitas modern (Rofhani 2017).

Pada bagian awal saya telah menyampaikan informasi terkait jumlah pengguna internet dan media sosial di Indonesia yang mencapai 88,1 juta orang dan menempatkan Indonesia sebagai negara pertama se-ASEAN dengan jumlah pengguna internet terbanyak. Data tersebut menunjukkan bahwa sebagian besar masyarakat Indonesia telah 'melek' media. Tingginya kepemilikan dan pemakaian gawai juga menjadi salah satu bukti kondisi 'melek' media, dewasa ini anak-anak kecilpun telah memiliki gawai dengan alasan supaya bisa berkomunikasi mudah dengan kedua orang tuanya. Pada kenyataannya media khususnya gawai tidak hanya berfungsi sebagai alat komunikasi satu dengan yang lainnya, 
namun juga berfungsi sebagai alat distribusi informasi, salah satunya yakni gaya hidup. Salah satu pengaruh media dalam kehidupan sosial masyarakat dapat terlihat pada ranah gaya hidup. Pada konteks ini, media berupaya mengkonstruksi suatu gaya hidup melalui konten-konten informasi, berita, artikel maupun gambar atau foto yang disebarkannya. Pernyataan tersebut merupakan aplikasi dari konsep Ibrahim dan Akhmad (2014) media dalam hal ini berperan sebagai pembentuk (constructors) melalui isi yang disebarkan oleh media yang memiliki kekuatan untuk memengaruhi masa depan masyarakat.

Konsep tersebut juga penulis pakai untuk melihat masyarakat Tambak Lorok khususnya dalam kajian konstruksi gaya hidup. Kepemilikan gawai maupun media elektronik yang lain menjadi salah satu faktor yang turut berpengaruh dalam proses kontruksi gaya hidupnya. Mengingat masyarakat akan melihat tayangan televisi atau youtube, lalu masyarakat juga akan mendengar informasi dari radio termasuk masyarakat juga akan melihat perkembangan gaya hidup melalui unggahanunggahan di media sosial. Berbagai macam bentuk informasi tersebut akan disaring dan ditelaah sebelum akhirnya diaplikasikan dalam kehidupan sehari-hari. Berdasar pada beberapa hal tersebut, maka dalam kajian penelitian ini akan berfokus pada tiga hal yakni persepsi perempuan pesisir atas gaya hidup, faktor yang berpengaruh pada proses konstruksi gaya hidup dan makna yang ingin disampaikan perempuan melalui gaya hidupnya.

Tingginya tingkat konsumsi masyarakat atas pangan, sandang dan kebutuhan tersier lainya menjadi salah satu latar belakang utama dalam proses kajian ini. Dewasa ini berbagai bentuk konsumsi tidak hanya bertujuan untuk memenuhi kebutuhan secara fisik saja namun juga merambah pada pemenuhan kebutuhan secara simbolik. Dengan demikian unsur lain selain entitas atas barang juga sangat diperhatikan dalam proses konsumsi. Proses konsumsi simbolik menjadi salah satu proses pembentukan gaya hidup individu. Oleh karena itu, rumusan permasalahan dalam kajian ini yakni "Bagaimana proses konstruksi gaya hidup perempuan Muslim pesisir?" Guna memperjelas dan men-riil kan kajian ini, rumusan permasalahan tersebut diturunkan kedalam tiga pertanyaan penelitian: 1) Faktor apasajakah yang berpengaruh dalam proses konstruksi gaya hidup pada perempuan Muslim pesisir? Apakah parameter sosial dijadikan indikator dalam konstruksi gaya hidup? 2) Bagaimana persepsi masyarakat khususnya perempuan Muslim pesisir atas gaya hidup? Apakah masyarakat memiliki rujukan tersendiri atas definisi gaya hidup? (3) Apa makna yang ingin disampaikan perempuan Muslim pesisir melalui gaya hidup?

Kajian atas gaya hidup pada masyarakat pesisir telah dilakukan oleh beberapa pihak, hal tersebut dikarenakan masyarakat pesisir menjadi salah satu tipe masyarakat yang menarik karena memiliki karakter tersendiri, khususnya tradisi yang berbeda dengan masyarakat petani yang lebih mendominasi di wilayah Pulau Jawa. Selain memiliki karakter yang berbeda dalam konteks nilai kultural dan norma sosial, masyarakat pesisir juga memiliki ciri khas lain jika kita merujuk pada berbagai macam stereotype yang merujuk pada masya- 
rakat pesisir terlebih pada konteks kajian gaya hidup (stereotype yang menyampaikan bahwa masyarakat pesisir memiliki karakter yang boros dan gengsi yang tinggi untuk menunjukkan gaya hidupnya). Seperti kajian penelitian yang telah dilakukan oleh Bela Dewi Purwanti dengan judul "Gaya Hidup Masyarakat Nelayan" (2013). Pada kajian penelitian tersebut Bela Dewi Purwanti berfokus pada upaya analisis gaya hidup dan kebiasaan yang dilakukan oleh nelayan, khususnya ketika para nelayan memanfaatkan hasil berlayar. Kajian tersebut juga memaparkan pola konsumsi yang dilakukan oleh nelayan di Desa Grajagan Kecamatan Purwoharjo Kabupaten Banyuwangi pasca mendapatkan hasil panen laut. Berdasar pada data penelitian yang didapatkannya, Bela Dewi lantas menyampaikan satu kesimpulan bahwa masyarakat nelayan Desa Grajagan mempunyai gaya hidup konsumtif dan matrelialistis dan alasan masyarakat nelayan masih mempertahankan gaya hidup tersebut (Purwanti 2013).

Kajian penelitian gaya hidupyang dilakukan juga mengarah pada beberapa faktor yang berpengaruh pada proses konstruksi gaya hidup, seperti media yang turut dijadikan indikator utama dalam melihat konstruksi gaya hidup pada perempuan Muslim pesisir Tambak Lorok Kajian penelitian untuk melihat pengaruh media terhadap proses konstruksi gaya hidup juga dilakukan oleh Handajani (2006) yang kemudian dituangkan dalam tulisan jurnal yang berjudul “Female's Sexuality in Indonesian Girls Magazines: Modern Appearance, Traditional Attitude". Pada tulisannya, Handajani mengungkapkan efektivitas peran media terhadap konstruksi gaya hidup individu. Media massa juga dipandang menjadi aktor penting dalam proses desiminasi informasi terkait dengan gaya hidup. Pernyataan tersebut dilatarbelakangi oleh sifat dari media massa yang efektif dan efisien dalam mendistribusikan berbagai informasi kepada publik. Sejalan dengan itu hadirnya sistem layanan data internet juga turut memaksimalkan kinerja media massa dalam mendistribusikan berbagai informasi, khususnya gaya hidup. Jika ditilik kembali dalam konteks kajian gaya hidup, majalah menjadi satu media yang layak dijadikan pusat analisis dengan kompleksitas kontennya. Pernyataan tersebut merujuk pada Handajani yang menyatakan bahwa media memiliki konten yang lucu, riang dan menyenangkan dengan cara ilustrasi menarik berikut dengan warna dan gayanya (Handajani 2006).

Faktor utama yang membedakan kajian ini dengan dua kajian tersebut terletak pada latar belakang masyarakat yang menjadi objek kajian dalam penelitian ini. Jika pada penelitian Purwanti (2013) mengkaji gaya hidup nelayan saja, namun pada konteks penelitian ini objek kajiannya tidak merujuk pada masyarakat saja melainkan pada objek yang lebih spesifik yakni perempuan. Menurut asumsi penulis, perempuan menjadi sosok yang menarik dalam kajian gaya hidup mengingat perempuan biasanya memiliki tingkat kepekaan dan kesadaran atas gaya hidup yang lebih apabila dibandingkan dengan laki-laki. Unsur lain yang menjadi titik pembeda dalam penelitian ini juga merujuk pada latar belakang agama objek kajian 
dalam penelitian ini (perempuan), mengingat dalam konteks ini latar belakang agama juga diperhatikan yakni agama islam. Oleh karena itu kajian ini akan berfokus pada perspektif yang lebih spesifik yakni konstruksi gaya hidup perempuan Muslim pesisir.

Penelitian ini menggunakan metode kualitatif. Lokasi utama penelitian adalah Tambak Lorok, Kota Semarang. Fokus utama penelitian ini adalah konstruksi gaya hidup perempuan Muslim pesisir, bagaimana perempuan memaknai dan memiliki pengalaman dalam proses kontruksi gaya hidup. Pola konsumsi atas barang dan jasa memiliki makna penting dalam konteks kajian ini karena akan terkait dengan simbol dan stratifikasi sosial masyarakat. Penggalian data dilakukan dengan beberapa cara, pertama yakni Focus Group Disscussion (FGD) dengan beberapa perempuan Muslim pesisiruntuk mengetahui pola konsumsi dalam kehidupan kesehariannya termasuk beberapa persoalan yang dialaminya.

Teknik penggalian data kedua yang dipakai adalah indepth interview atau wawancara mendalam person by person untuk mendapatkan pemahaman yang holistik. Metode ini digunakan untuk mengkaji pengalaman dan pemaknaan yang dimiliki dan dirasakan oleh masing-masing perempuan Muslim pesisir. Metode ini harus dilakukan dalam melakukan kajian karena setiap individu akan memiliki pengalaman, perasaan, persoalan dan pemaknaan sendiri-sendiri. Oleh karena adanya perbedaan tersebut, maka penggalian data harus dilakukan dengan metode khusus yakni wawancara mendalam untuk mendapatkan pemahaman yang dalam. Metode lain yang digunakan yakni dengan arsip dan dokumenter, kajian atas arsip dan dokumen menjadi metode penting guna melihat korelasi data dalam rentang waktu yang lain.

\section{Perempuan Muslim Tambak Lorok}

Tambak Lorok merupakan kawasan pesisir Semarang yang cukup menarik perhatian publik belakangan ini. Pada umumnya kampung nelayan seringkali diidentikkan dengan citra kumuh, kotor dan padat penghuni karena semua kegiatan terorientasi di pinggiran laut. Citra tersebutlah yang nampak ingin diubah oleh pemerintah dengan menjadikan Tambak Lorok sebagai Kampung Wisata Bahari berdasar pada sumber daya alam yang dimiliki oleh Tambak Lorok. Sarana dan prasarana Tambak Lorok dibangun untuk mempersiapkan dibukanya Kampung Wisata Bahari Tambak Lorok, mulai dari akses jalan menuju Tambak Lorok, fasilitas-fasilitas umum seperti Rumah Apung Tambak Lorok hingga dermaga sebagai meeting point di Tambak Lorok. Secara administratif, Tambak Lorok terletak di Kelurahan Tanjung Mas Kecamatan Semarang Utara. Meskipun terletak di pinggiran laut, namun aktivitas perekonomian dan sosial masyarakat Tambak Lorok dapat dikategorikan dalam intensitas tinggi. Pasalnya aktivitas jual beli yang berlangsung di pasar Tambak Lorok tidak pernah sepi dari pagi hingga malam. Selain berprofesi sebagai nelayan, sebagian masyarakat Tambak Lorok juga berprofesi sebagai pengrajin ikan asin dan berbagai olahan ikan seperti petis ikan, oleh karena itu Tambak Lorok menjadi pusat jual 
beli hasil laut, khususnya ikan asin. Lokasinya yang berdekatan dengan Pelabuhan Tanjung Mas Semarang juga menjadi salah satu faktor yang melatarbelakangi tingginya intensitas jual beli hasil laut khususnya ikan asin, mengingat hasil olahan ikan kemudian juga dikirim ke beberapa daerah di Indonesia.

Tambak Lorok merupakan dataran rendah di Semarang yang rentan akan bahaya rob. Lokasinya yang berada di pinggir laut juga menjadi pengaruh yang signifikan atas besarnya potensi rob di Tambak Lorok. Beberapa upaya sering dilakukan oleh masyarakat setempat untuk menanggulangi terjadinya rob, mulai dari membuat barrier menggunakan karung sak pasir hingga pada meninggikan bagunan rumah setiap tahun. Pada dasarnya rob tidak hanya berdampak pada lingkungan Tambak Lorok, namun juga menjadi faktor penghambat utama dalam keseharian masyarakat mengingat ketinggian air rob yang tinggi (seringkali setinggi lutut orang dewasa). Karakteristik lingkungan Tambak Lorok berdampak pada pola hidup masyarakat sebagai hasil dari adaptasi yang dilakukakan oleh masyarakat. Berbagai kerentanan lingkungan tersebut tidak lantas menjadikan Tambak Lorok sebagai lokasi yang minim penghuni, namun justru menjadikan Tambak Lorok sebagai kawasan yang padat penghuni. Salah satu faktor yang melatarbelakangi tingginya kepadatan penduduk di Tambak Lorok adalah lokasinya yang berada di pinggir laut, mengingat laut telah dijadikan sebagai 'sumber kehidupan' bagi nelayan dan jenis profesi lain yang berkaitan dengan pemanfaatan hasil laut. Berdasar pada hasil penghitungan penduduk tahun 2015 yang di- lakukan oleh Kelurahan Tanjung Mas, jumlah keseluruhan penduduk di Tambak Lorok adalah 9.503 penduduk dengan rincian jumlah penduduk perempuan 5.130 jiwa, sedangkan jumlah penduduk laki-laki 4.373 jiwa. Sedangkan Tambak Lorok memiliki area seluas 323, 782 Ha yang terdiri dari 271, 782 Ha lahan kering dan 52 Ha lahan basah atau tambak yang menjadi lapangan pekerjaan bagi beberapa masyarakat Tambak Lorok. ${ }^{1}$

Jika ditinjau kembali terkait sejarah desa Tambak Lorok, penduduk Tambak Lorok merupakan migran dari daerah-daerah lain di sekitar Semarang khususnya Demak. Faktor utama yang melatarbelakangi perpindahan tersebut adalah profesi sekelompok masyarakat yakni nelayan dan jenis profesi lain yang berhubungan dengan pemanfaatan sumber daya laut. Secara geografis Tambak Lorok tidak representatif untuk dijadikan tempat hunian, mengingat lokasi Tambak Lorok merupakan daerah rendah dengan kemiringan $0-2 \%$ dan berbatasan langsung dengan Laut Jawa sehingga sangat berpotensi terjadi rob. Selain itu Tambak Lorok memiliki curah hujan 27,7 $34,8 \mathrm{~mm} /$ tahun sehingga masuk dalam kategori daerah dengan curah hujan sedang sampai tinggi. Kondisi tersebut tidak diimbangi dengan ketersediaan sistem drainase yang baik oleh masyarakat dan belum menjadi prioritas pembangunan pemerintah setempat. Sehingga daerah Tambak Lorok merupakan daerah yang rentan banjir. Meskpun demikian, kondisi geografis tersebut tidak menjadi faktor peng-

1 Profil Tambak Lorok Tahun 2015 pada Kantor Kelurahan Tanjung Mas. 
hambat mobilitas dan perpindahan masyarakat ke Tambak Lorok. Namun masyarakat kelompok masyarakat justru nampak mengembangkan survival strategy untuk merespons kondisi tersebut.

Tambak Lorok menjadi daerah pesisir yang sedikit berbeda dengan daerah pesisir lain di sepanjang Pantai Utara Jawa. Meskipun terletak di arteri Kota Semarang namun keberadaan Tambak Lorok nampak tidak seperti daerah yang berada di pusat kota. Terbatasnya sarana dan prasarana di Tambak Lorok menjadi salah satu faktor yang melatarbelakangi kondisi tersebut. Sehingga tidak banyak aktivitas dan interaksi yang dilakukan oleh masyarakat Tambak Lorok kecuali persoalan jual beli ikan dan olahan ikan. Namun praktik yang kerap terjadi adalah para tengkulak akan mengambil hasil laut dan olahan ikan yang menjadi komoditas utama Tambak Lorok. Aktivitas keseharian masyarakat terfokus di Tambak Lorok dan kampung nelayan di sekitarnya seperti Tambak Rejo dan Tambak Mulyo, mengingat sebagian besar masyarakat berprofesi sebagai nelayan dan pemilik tambak ikan. Seperti yang telah disampaikan pada bagian sebelumnya keterbatasan sarana dan prasarana menjadi salah satu faktor yang berdampak signifikan pada keseharian masyarakat. Tambak Lorok hanya memiliki satu akses jalan utama yang menghubungkan Tambak Lorok dengan jalan arteri Semarang, namun kondisinya kurang layak untuk dilalui kendaraan roda empat sehingga mobilitas masyarakat banyak dilakukan dengan sepeda motor. Jalan tanah yang bergelombang dan digenangi air menjadi permasalahan utama akses jalan di Tambak Lorok. Kondisi tersebut dilatarbelakangi oleh tidak adanya sistem drainase di sepanjang jalan utama Tambak Lorok. Namun, dalam rangka mempersiapkan Kampung Wisata Bahari Tambak Lorok, pemerintah mulai membangun beberapa fasilitas termasuk perbaikan jalan utama pada tahun ini dan masih berlangsung hingga saat ini. Berbagai keterbatasan tersebut berdampak pula pada bentuk-bentuk kerentanan yang menaungi masyarakat Tambak Lorok termasuk perempuan Tambak Lorok.

Pertama yakni kerentanan fisik yang dilatarbelakangi oleh keterbatasan sarana dan prasarana di Tambak Lorok seperti akses jalanan yang rusak dan sistem drainase yang tidak memadai seperti yang telah disebutkan pada bagian sebelumnya. Kondisi tersebut berdampak pada kelayakan rumah atau hunian milik masyarakat. Permasalahan tahunan yang dialami oleh masyarakat yakni turunnya rumah akibat dari penurunan permukaan tanah. Masyarakat harus merenovasi dan meninggikan rumah setiap tahunnya untuk meminimalisisasi masuknya air ke dalam rumah. Persoalan kesehatan juga menjadi permasalahan yang masuk dalam kerentanan fisik perempuan Tambak Lorok. Selain genangan air, perempuan Tambak Lorok juga dihadapkan dengan persoalan sampah baik sampah rumah tangga maupun sampah laut. Masyarakat Tambak Lorok belum memiliki sistem pengelolaan sampah yang berkelanjutan, meskipun beberapa program pengelolaan sampah dari komunitas dan LSM telah disosialisasikan namun kebiasaan untuk pengelolaan sampah belum maksimal di Tambak 
Lorok. Hal tersebut berdampak pada pola hidup dan kesehatan perempuan Tambak Lorok. Masyarakat terbiasa membuang sampah tidak pada tempatnya hingga pada akhirnya sampah-sampah tersebut bermuara di sungai dan laut. Oleh karena itu, penyakit demam berdarah menjadi salah satu jenis penyakit dominan di Tambak Lorok. Perempuan dan anak memiliki potensi lebih tinggi jika dibanding dengan laki-laki, mengingat perempuan dan anak lebih banyak menghabiskan waktu dirumah. Belakangan pemberantasan jentik nyamuk menjadi program prioritas dari kelurahan setempat. Fasilitas TPI yang kurang memadai juga menjadi penyumbang ketidakhigienisan lingkungan Tambak Lorok. Masyarakat Tambak Lorok melakukan transaksi jual beli ikan menggunakan cara dan sarana tradisional sehingga belum ada sistem pengolahan limbah TPI.

Kedua adalah kerentanan sosial yang ditanggung oleh perempuan Tambak Lorok. Tinggal di lokasi pesisir pantai ditambah dengan kondisi sarana dan prasarana yang kurang memadai faktanya menghambat berbagai bentuk aktivitas perempuan Tambak Lorok. Pendidikan merupakan salah satu ranah yang kurang diprioritaskan bagi sebagian besar perempuan Tambak Lorok. Tidak banyak perempuan Tambak Lorok yang memiliki latar belakang pendidikan tinggi, sebagian besar hanya menamatkan pendidikan sekolah dasar saja. Namun tiga tahun belakangan ini, beberapa masyarakat Tambak Lorok mulai memperhatikan pendidikan anak-anaknya dengan berupaya menamatkan pendidikan SMA atau sederajat. Selain sarana dan prasarana di sekitar Tambak Lorok kurang memadai, aktivitas kesehariannya yang terpusat pada pengelolaan hasil laut juga menjadi satu faktor yang melatarbelakangi rendahnya tingkat pendidikan perempuan Tambak Lorok. Kerentanan tersebut berdampak pada jenis kerentanan yang ketiga yakni kerentanan ekonomi perempuan Tambak Lorok. Rendahnya tingkat pendidikan Tambak Lorok berdampak langsung pada jenis profesi perempuan Tambak Lorok. Jenis pekerjaan informal menjadi alternatif bagi perempuan Tambak Lorok untuk mendapatkan sumber penghasilan. Terlebih era globalisasi mensyaratkan pekerja memiliki ketrampilan khusus. Jenis pekerjaan yang dimiliki oleh perempuan Tambak Lorok adalah pedagang baik pedagang kelontong kebutuhan sembako di pasar maupun pedagang hasil tangkapan nelayan. Khusus di RW 12 perempuan beberapa perempuan Tambak Lorok justru mengolah hasil tangkapan ikan nelayan untuk diolah menjadi ikan asin dan petis ikan. Belakangan muncul alternatif pekerjaan baru yakni sebagai buruh di beberapa perusahaan bongkar muat dan ekspedisi pengiriman hasil olahan laut, sektor pekerjaan ini biasanya menyasar pada perempuan Tambak Lorokyang berusia remaja.

Berdasar pada beragamnya temuan di Tambak Lorok, maka dalam rangka mengkaji persoalan konstruksi gaya hidup perempuan Tambak Lorok penulis membuat pemetaan gaya hidup pada perempuan Tambak Lorok. Pertimbangan utama pemetaan perempuan Tambak Lorok ini berdasar pada perbedaan faktor-faktor utama yang berpengaruh signifikan pada proses konstruksi gaya hidup per- 
empuan Tambak Lorok antara lain usia, latar belakang pendidikan dan jenis profesi yang dimiliki oleh perempuan Tambak Lorok.

\section{Signifikansi Sosiokultural dan Media dalam Konstruksi Gaya Hidup}

Kajian atas gaya hidup penting untuk dilakukan karena hal tersebut tidak hanya berkaitan dengan pemenuhan kebutuhan primer saja. Pada kenyataannya kegiatan konsumsi tidak menjadi hak prioritas individu sepenuhnya. Terdapat beberapa faktor yang berpengaruh secara signifikan atas proses konstruksi gaya hidup individu. Salah satu faktor yang dimaksud adalah latar belakang etnis dari individu. Pada konteks ini pembentukan gaya hidup perempuan Muslim Tambak Lorok tidak hanya berkaitan dengan kegiatan pemenuhan kebutuhan saja namun justru merujuk pada kondisi kultural dan sosial masyarakat yang membentuk gaya hidup secara tidak langsung. Terdapat beberapa faktor yang turut berpengaruh pada proses konstruksi gaya hidup seperti latar belakang etnis, letak geografis atau tempat tinggal individu dan media. Beberapa faktor tersebut akan menjadi unsur negoisasi atas konstruksi gaya hidup individu. Dengan kata lain gaya hidup dapat diinterpretasikan sebagai cerminan dari individu dan masyarakat yang tinggal dilingkungan sekitarnya. Dengan demikian proses konstruksi dan pemaknaan atas gaya hidup akan berbeda-beda.

Lokasi Tambak Lorok Semarang yang berada di wilayah pesisir utara Jawa menjadi salah satu lokasi yang menarik menurut penulis. Hal tersebut dikarenakan Tambak Lorok adalah wilayah pesisir yang tidak berjarak jauh dengan wilayah perkotaan Semarang, dalam praktiknya kemudian berlangsung proses negoisasi sehingga Tambak Lorok menjadi wilayah pesisir yang memiliki karakter tersendiri. Kajian atas konstruksi gaya hidup juga dirasa penting untuk dilakukan di Tambak Lorok mengingat adanya stereotype yang berkembang dalam ranah akademis maupun ranah praktis. Stereotype yang dimaksud terkait dengan karakter masyarakat pesisir dan non pesisir dalam konteks kegiatan konsumsi. Asumsi dasar dengan merujuk pada stereotype tersebut bahwa masyarakat pesisir termasuk dalam tipe masyarakat yang boros dan suka menghamburkan uang, selain itu masyarakat pesisir juga dikenal dengan tipe masyarakat dengan tingkat konsumsi atas barang dan jasa tinggi. Persoalan tersebut lantas merujuk pada karakter masyarakat pesisir yang harus menjaga gengsinya, sehingga masyarakat pesisir akan menunjukkannya dengan kepemilikan barangnya (kegiatan konsumsi) yang merujuk pada konstruksi gaya hidup atas dirinya. Berdasar pada pernyataan tersebut maka kajian atas gaya hidup di Tambak Lorok menjadi kajian yang krusial untuk melihat bagaimana perempuan pesisir Tambak Lorok mengkonsepkan dan memaknai gaya hidup sebagai individu yang tinggal di wilayah pesisir. Kajian konstruksi gaya hidup perempuan Muslim di pesisir Tambak Lorok juga akan menambah referensi atas kajian islam dan masyarakat. Pada konteks ini nilai-nilai dan ajaran islam turut menjadi bahan acuan untuk melihat gaya hidup para perempuan Muslim di pesisir Tambak Lorok. 
Jika meninjau kembali kondisi geografis Tambak Lorok, maka pada dasarnya lokasi Tambak Lorok kurang representatif untuk dijadikan pemukiman. Namun, tuntutan perekonomian yang tinggi membuat masyarakat harus berada dan tinggal dekat dengan laut untuk mempermudah aktivitas melaut, mengelola tambak dan mengolah hasil laut lainnya. Masyarakat Tambak Lorok merupakan migran dari daerah sekitar Semarang, khususnya Demak yang berprofesi sebagai nelayan. Kelompok masyarakat tersebut pada akhirnya tinggal menetap dan beranak pinak di Tambak Lorok karena mendekati laut yang menjadi sumber penghasilan. Pada awalnya dibangun rumah singgah yang dipakai untuk beristirahat sebelum dan pasca melaut, namun seiring dengan berjalannya waktu rumahrumah tersebut terus direhab hingga menjadi rumah permanen. Meskipun demikian masih bisa ditemukan beberapa rumah yang konsep bangunannya masih berupa rumah nonpermanen. Beberapa bagian di Tambak Lorok justru tengah melakukan negosiasi dengan pemerintah setempat untuk mempertahankan lahan yang kini ditinggalinya. Proses negosiasi tersebut sebagai respons atas kebijakan pemerintah yang akan merelokasi beberapa bagian pemukiman masyarakat untuk membangun aliran banjir kanal timur dan persiapan pembentukan Kampung Wisata Bahari Tambak Lorok.

Berdasar pada mobilitas penduduk tersebut maka latar belakang perempuan Tambak Lorok adalah suku bangsa Jawa, mengingat Demak merupakan salah satu wilayah administrasi yang masuk dalam kawasan suku bangsa Jawa. Selain itu, Demak juga memiliki karakteristik lain yakni terkait religiusitasnya. Seperti yang diketahui masyarakat pada umumnya, daerah Pantai Utara Jawa termasuk Demak merupakan daerah yang erat dengan tradisi keislamannya. Terdapat banyak pondok pesantren yang dipimpin oleh ulamaulama besar. Demak juga menjadi salah satu destinasi utama wisata religi dengan keberadaan masjid agung dan kompleks pemakaman wali hingga kegiatan pembelajaran islam melaui pondok pesantren. Oleh karena itu, masyarakat Demak seringkali dilekatkan dengan religiusitas yang tinggi. Adat, tradisi dan pola hidup yang diadopsi dari suku bangsa Jawa dan Islam turut terbawa ketika masyarakat melakukan mobilisasi ke Tambak Lorok Semarang, khususnya ketika masyarakat mulai tinggal menetap di daerah Tambak Lorok. Lingkungan geografis yang notabenenya berbeda antara Tambak Lorok dan Demak menuntut masyarakat untuk melakukan adaptasi dengan wilayah pesisir, baik secara fisik maupun sosial. Pada konteks ini secara tidak langsung terjadi proses akulturasi antara budaya Jawa-Islam dan Pesisir. Proses dinamika budaya tersebut faktanya tidak hanya berdampak pada pola hidup keseharian yang dimiliki oleh masyarakat, namun juga berpengaruh secara signifikan terhadap proses konstruksi gaya hidup. Nilai dan norma budaya terkonsep melalui ideal value yang diharapkan dijadikan acuan bagi seluruh anggotanya. Pada konteks ini ideal value yang dimiliki oleh budaya Tambak Lorok turut berpengaruh pada konteks konstruksi gaya hidup perempuan Tambak Lorok. Sehingga 
gaya yang terepresentasi merupakan gaya yang mengakomodasi ideal-ideal value yang dimiliki oleh masyarakat Tambak Lorok.

Kontruksi gaya hidup perempuan Muslim Tambak Lorok sejalan dengan konsep dialektika sosial Berger yang merujuk pada proses eksternalisasi, objektivasi dan internalisasi (Berger dan Luckman 1990). Gaya hidup tidak terbentuk begitu saja dalam jangka waktu yang singkat, namun terdapat proses dan tahapan pembentukan gaya hidup. Tahapan pertama pembentukan gaya hidup merujuk pada konsep eksternalisasi yang merupakan pengenalan dengan kondisi sosiokultural tempat individu tersebut tinggal. Pada konteks ini perempuan Tambak Lorok telah melakukan proses adaptasi terhadap lingkungan geografis pesisir. Upaya tersebut menjadi prioritas utama dalam melangsungkan kehidupan, mengingat terdapat perbedaan yang cukup signifikan antara kondisi geografi wilayah pesisir dan non pesisir. Oleh karena itu ideal value yang terbentuk dalam konteks gaya hidup tidak hanya merujuk pada latar belakang budaya Jawa melainkan juga mendapatkan pengaruh dari nilai dan norma islam yang diterapkan di lingkungan pesisir.

Tahapan yang kedua merujuk pada proses objektifikasi yang merupakan proses interaksi antara individu dengan masyarakat. Pada konteks ini individu akan mengalami penyesuaian dengan lingkungan sosial, tentu saja gaya hidup yang dimiliki oleh individu merupakan proses dialektika dengan berbagai unsur di lingkungan tempat tinggalnya. Proses ini menjadi penting bagi perempuan Tambak
Lorok mengingat proses adaptasi yang dilakukannya di lingkungan pesisir. Tahapan yang selanjutnya merujuk pada proses internalisasi yang merupakan proses identifikasi individu ditengah lingkungan sosiokultural masyarakat. Pada konteks ini pula masyarakat akan turut melakukan identifikasi atas individu untuk menempatkannya pada stratifikasi sosial tertentu. Faktanya masyarakat memiliki indikator tersendiri untuk mengklasifikasikan individu ke dalam stratifikasi sosial tertentu. Representasi gaya hidup menjadi salah satu realita yang dapat dipakai dalam proses klasifikasi tersebut. Terlebih pada konteks postmodernisme, representasi gaya hidup menjadi persoalan yang krusial untuk dikaji mengingat proses konsumsi juga merujuk pada semakin meningkatnya kesadaran masyarakat atas konsumsi simbol. Dengan kata lain, tujuan utama dari proses konsumsi bukan hanya untuk memenuhi kebutuhan secara substansial namun juga memenuhi kebutuhan secara simbolik. Pada konteks ini, konsumsi simbolik merujuk pada merk, model dan jenis barang atas barang yang dikonsumsi. Merk, model dan jenis barang menjadi penanda dan identitas atas barang yang kita konsumsi. Sehingga secara tidak langsung representasi gaya hidup akan berdampak pada konstruksi atas eksistensi diri perempuan Tambak Lorok tersebut. Pada konteks ini, tentu saja trend fashion setiap daerah akan berbeda karena memiliki latar belakang sosiokultural yang berbeda sehingga ideal value yang dipedomani berbeda pula.

Media menjadi faktor kedua yang berpengaruh signifikan terhadap proses kon- 
struksi gaya hidup perempuan Tambak Lorok. Kemajuan teknologi media dan informasi telah berdampak pada perubahan gaya hidup masyarakat. Pada kenyataannya media tidak hanya difungsikan sebagai distributor informasi terkini namun media juga berupaya mengkonstruksi suatu gaya hidup melalui konten-konten informasi, berita, artikel maupun gambar atau foto yang diunggahnya baik secara langsung maupun tidak langsung. Dengan demikian, pada konteks ini media menyebarkan informasi terkait dengan gaya hidup, maka secara tidak langsung media tengah berupaya untuk mengkonstruksi gaya hidup. Media seakan menjadi produsen gaya hidup yang berkembang dalam keseharian masyarakat. Keberadaan media berikut dengan peran dan fungsi media sangat krusial dalam keseharian masyarakat. Terdapat beberapa jenis media yang digunakan oleh perempuan Tambak Lorok, seperti media cetak, elektronik hingga pada media sosial (termasuk media maya/internet). Beberapa jenis media tersebut memang memiliki pengguna (user) yang berbeda. Perempuan Tambak Lorok yang berprofesi sebagai ibu rumah tangga cenderung menggunakan media elektronik seperti televisi sebagai referensi utama dalam melakukan update berita dan informasi terkini, termasuk update gaya hidup. Penggunaan media eletronik seperti televisi menjadi relevan jika dikaitkan dengan kegiatan keseharian perempuan Tambak Lorok yang terfokuskan di rumah. Pola penggunaan media yang sedikit berbeda terlihat pada perempuan Tambak Lorok yang berprofesi sebagai buruh begitu juga pola penggunaan media pada perempuan usia remaja dan mahasiswa. Meskipun jumlah perempuan Tambak Lorok yang tengah menempuh studi sarjana masih sangat sedikit. Selain media elektronik, mereka juga menggunakan media sosial/maya sebagai referensi utama dalam mencari alternatif gaya. Terlebih konten-konten di beberapa media sosial seperti instagram dan facebook yang telah membuat klasifikasi tersendiri khusus untuk isu gaya hidup (life style). Unggahan di media sosial yang mendapatkan respons banyak (like dan comment) biasanya akan menjadi viral dan secara tidak langsung menjadi satu gaya yang 'dianggap' terkini. Oleh karena itu, pengguna media sosial yang lain akan turut mengikuti gaya yang ditampilkan dalam media sosial tersebut. Lantas besar kemungkinan gaya hasil dari proses meniru tersebut juga akan diunggah dalam media sosial untuk mendapatkan legitimasi pula bahwa individu tersebut masuk dalam kategori perempuan 'zaman now'. Realita tersebut sejalan dengan pendapat Bordieu yang saya kutip dari tulisan Abdullah, bahwa kaum muda memainkan peran sebagai perantara kebudayaan yang sekaligus merupakan konsumen potensial untuk memainkan peran sebagai perantara dalam distribusi produkproduk modern (Abdullah 1994; baca: Ben dan Leopold 1993; Bertens 1995) Masyarakat khususnya remaja sebagai konsumen global akan berusaha menunjukkan status dan stylenya melalui berbagai aksesoris yang menyertainya khususnya pakaian. Mereka pada umumnya ingin disebut sebagai individu yang selalu mengikuti tren agar keberadaannya diakui (Rubiyanti 1998). Begitu pula yang 
terjadi dalam keseharian perempuan Tambak Lorok dimana tren yang populer di media sosial kemudian menjadi indikator utama untuk merepresentasikan gaya hidup.

\section{Aktualisasi dan Persepsi Perempuan Muslim Pesisir atas Gaya Hidup}

Menurut Koentjaraningrat, gaya hidup merupakan pola tingkah laku sehari-hari segolongan manusia dalam masyarakat yang diamati dan memberi arti khusus kepada golongan itu (Koentjaraningrat 1990). Sedangkan menurut Chaney, gaya hidup merupakan bentuk khusus pengelompokan status modern (Chaney 2011). Pentingnya mengkaji gaya hidup yang dimiliki oleh masyarakat sejalan dengan teori konstruksi gaya hidup milik Chaney, "gaya hidup kita membantu mendefinisikan sikap, nilai-nilai, dan menunjukkan kekayaan serta posisi sosial kita" (Chaney 2011). Namun, pada konteks ini aktualisasi gaya hidup perempuan Tambak Lorok cenderung dikaji melalui gaya berpenampilan (fashion) yang dikenakan oleh individu. Pemilihan fokus kajian tersebut didasari dengan adanya asumsi bahwa gaya berpenampilan (fashion) merupakan fenomena yang dapat diamati dan dapat memberikan arti khusus kepada perempuan Tambak Lorok. Selain itu gaya berpenampilan (fashion) merupakan fenomena yang dapat terlihat secara langsung, sehingga dapat dengan mudah untuk dilakukan pengamatan dan analisis terkait representasi identitas perempuan Tambak Lorok.

Pada bagian sebelumnya telah dipaparkan dua faktor yang melatarbelakangi konstruksi gaya hidup perempuan Tambak Lorok. Aktual- isasi gaya hidup perempuan Tambak Lorok dalam kehidupan keseharian merupakan bentuk respons terhadap ideal value yang dikonstruksi secara sosiokultural (JawaMuslim-pesisir). Oleh karena itu yang terepresentasi dari perempuan Muslim Tambak Lorok adalah gaya berpakaian yang sesuai dengan kondisi sosiokultural setempat. Konsep sopan menjadi prioritas utama dalam mengekspresikan gaya hidup yang dikaji melalui gaya penampilan (fashion). Pada konteks ini konsep sopan yang dimaksud merujuk pada upaya menutup aurat dalam berbusana, meskipun perempuan Tambak Lorok tinggal di wilayah pesisir laut yang nota benenya cenderung lebih panas jika dibandingkan dengan wilayah yang lain. Namun demikian praktik konsep sopan dalam berbusana yang merujuk pada nilai dan norma islam nampak dinegosiasi dengan budaya Jawa serta lingkungan fisik (geografis). Sehingga yang terepresentasi dalam keseharian perempuan Tambak Lorok yang memiliki latar belakang sebagai pedagang dan ibu rumah tangga yakni penggunaan kerudung. Pada konteks ini definisi operasional berkerudung tidak hanya merujuk pada bentuk kerudung persegi ataupun persegi panjang yang disematkan secara rapi hingga menutupi kepala, rambut dan menjulur sampai ke dada saja. Namun ada jenis dan pola penggunaan kerudung lain yang dikenakan dalam keseharian perempuan Muslim pesisir yakni dengan menggunakan 'kupluk' atau turban yang hanya menutupi rambut saja. Pola penggunaan tersebut akan sedikit berbeda dengan kelompok pengguna perempuan Tambak Lorok yang berprofesi 
sebagai buruh (bekerja di luar Tambak Lorok), mahasiswi serta remaja perempuan Tambak Lorok yang cenderung menggunakan kerudung dengan menyematkannya secara rapi dan menutupi kepala secara keseluruhan hingga menjulur ke dada. Perbedaan pola penggunaan tersebut dilatarbelakangi oleh pertimbangan efisiensi dan efektivitas penggunaan kerudung bagi masing-masing kelompok perempuan di Tambak Lorok.

Konsep sopan dalam berpenampilan juga ditunjukkan melalui pemilihan model baju keseharian perempuan Tambak Lorok. Meskipun tinggal di wilayah pesisir pantai, model baju yang dikenakan oleh perempuan Tambak Lorok tetap merujuk pada ideal value yang dimiliki oleh masyarakat Tambak Lorok. Meskipun terletak di pinggiran pantai yang nota benenya cenderung panas, namun pakaian keseharian yang dipakai oleh perempuan Tambak Lorok khususnya yang remaja tidak lantas jenis pakaian yang terbuka seperti celana hot pants serta singlet saja. Perempuan Tambak Lorok justru menggunakan pakaian dengan tipe dan model baju sewajarnya seperti baju berlengan serta celana atau rok minimal selutut jika kebetulan tidak mengenakan kerudung. Sistem sosial menjadi alat kontrol yang efektif dan efisien dalam rangka menjaga konsep sopan dalam berpakaian, sepertihalnya penuturan beberapa perangkat desa (istri dari perangkat desa) yang beberapa kali menegur orang tua dari remaja perempuan yang mengenakan pakaian yang tidak sopan berdasarkan standarisasi kesopanan masyarakat Tambak Lorok.
Penggunaan aksesoris juga menjadi ruang untuk merepresentasikan gaya hidup perempuan Tambak Lorok. Pada konteks ini, aksesoris yang dimaksud yakni penggunaan perhiasan emas dalam keseharian perempuan Tambak Lorok. Hal tersebut dikarenakan penggunaan aksesoris emas menjadi satu indikator untuk menentukan stratifikasi sosial dalam masyarakat. Penggunaan aksesoris emas pada perempuan Tambak Lorok menjadi satu persoalan yang krusial. Beberapa perempuan Tambak Lorok justru terbiasa menggunakan aksesoris emas seperti gelang, kalung dan cincin dalam jumlah yang banyak baik dalam segi kuantitas serta kualitas (jumlah kadar emas dalam setiap model perhiasan yang dipakai). Sehingga yang terlihat dalam keseharian, perempuan Tambak Lorok terbiasa menggunakan gelang dan kalung lebih dari satu bahkan seringkali ditumpuk-tumpuk. Identifikasi strata sosial akan mudah dilakukan mengingat perhiasan yang berjumlah banyak tersebut biasa dikenakan di bagian tubuh yang terlihat seperti tangan dan leher namun dipakai setelah pakaian. Dengan kata lain, meskipun mengenakan kerudung namun perhiasan emas akan tetap terlihat karena dikenakan di atas lapisan kerudung (di atas lapisan baju). Tidak hanya perempuan dengan latar belakang strata sosial menengah keatas yang mengenakan perhiasan emas, namun perempuan dengan strata sosial menengah ke bawah juga cenderung menempatkan perhiasan emas sebagai prioritas, terlebih jika menghadiri suatu kegiatan kampung. Pernyataan tersebut merujuk pada beberapa perempuan Tambak Lorok yang tergolong 
dalam kategori sosial menengah kebawah yang merasa minimal harus punya satu perhiasan (biasanya cincin dan gelang) yang bisa dikenakan, meskipun kadar emasnya hanya sedikit (1 gram misalnya). Penggunaan perhiasan emas tersebut ditujukan supaya perempuan dirasa atau dianggap 'pantes' oleh lingkungan sosial Tambak Lorok secara keseluruhan.

Kontrol sosial menjadi langkah alternatif dalam representasi gaya hidup perempuan Tambak Lorok. Kondisi tersebut dilatarbelakangi dengan proses internalisasi ideal value yang sama dalam lingkungan sosiokultural Tambak Lorok. Perempuan Tambak Lorok kemudian memiliki perspektif yang sama terkait ideal value yang menjadi pertimbangan utama dalam representasi gaya hidup. Oleh karena itu gaya hidup yang terepresentasi merupakan mass style atau gaya hidup massal. Perempuan Tambak Lorok cenderung mengkonstruksi gaya hidup dengan orientasi dan model yang sama. Meskipun fungsi utama dalam proses konstruksi gaya hidup adalah menjadi unsur pembeda, namun pada konteks ini perempuan Tambak Lorok cenderung menggunakan model dan jenis penampilan yang sama. Pada kenyataannya ketika ada suatu model dan jenis penampilan yang dianggap sopan dan pantes, maka model dan jenis penampilan tersebutlah yang akan dijadikan acuan atau referensi perempuan Tambak Lorok yang lain. Kondisi tersebut dilatarbelakangi oleh adanya asumsi bahwa gaya hidup merupakan representasi dari identitas perempuan Tambak Lorok yang tujuan utamanya yakni mendapat eksistensi dalam ruang sosiokultural. Dengan kata lain representasi gaya hidup merupakan suatu cara yang digunakan untuk mendapatkan pengakuan dari orang lain. Pada konteks ini ideal value digunakan sebagai alat pengukur yang terkonstruk melalui lingkungan sosiokultural yang sama. Sehingga perempuan Tambak Lorok memiliki orientasi yang sama terkait gaya hidup.

\section{Kesimpulan}

Pada awal perkembangannya tidak banyak kalangan akademisi yang menaruh perhatian lebih pada isu konsumsi dan gaya hidup, mengingat isu tersebut justru dianggap sebagai suatu hal yang alamiah atau naluriah saja. Pernyataan tersebut dilatarbelakangi oleh adanya satu asumsi bahwa bentuk konsumsi merupakan suatu upaya untuk merespons dan memenuhi kebutuhan atas dirinya saja. Namun belakangan, kajian-kajian atas konsumsi dan gaya hidup mulai populer dikalangan akademis, diikuti dengan munculnya berbagai fenomenafenomena sosial yang terkait dengan proses konsumsi dan gaya hidup. Pada konteks ini perempuan Tambak Lorok menjadi representasi atas kegiatan konsumsi yang tidak hanya berkaitan dengan proses pemenuhan kebutuhan namun juga berkaitan dengan hidden goals yang melekat dalam proses konsumsi dalam rangka mengkonstruksi gaya hidupnya. Kajian konstruksi gaya hidup perempuan Muslim Tambak Lorok ini merujuk pada tiga simpulan kajian.

Simpulan pertama terkait dengan hidden goals yang melekat dalam kegiatan konsumsi yakni saving material. Pernyataan tersebut merujuk pada kegiatan konsumsi yang dilaku- 
kan oleh perempuan Tambak Lorok dalam bentuk aksesoris perhiasan emas dan kepemilikan gadget. Pada konteks ini justru banyak perempuan Tambak Lorok yang menekankan akan kepemilikan perhiasan emas jika dibandingkan dengan kebutuhan tersier lainnya. Kondisi tersebut dilatarbelakangi dengan adanya asumsi bahwa aksesoris emas menjadi perhiasaan utama bagi perempuan. Konsumsi emas dalam jumlah dan model yang banyak tidak hanya merujuk pada persoalan penggunaan emas sebagai aksesoris saja melainkan juga merujuk pada bentuk saving material. Perhiasan emas juga dianggap sebagai bentuk tabungan yang bersifat barang, sehingga jika pada suatu saat keluarga memerlukan kebutuhan lebih maka perhiasan emas dapat dijual atau digadaikan untuk mendapatkan dana cair. Praktik tersebut menjadi suatu hal yang lumrah dilakukan oleh perempuan. Kondisi tersebut menjadi alternative strategy yang dilakukan oleh perempuan untuk memiliki saving money dalam bentuk lain. Selain itu juga memiliki relevansi dengan way out atas stereotype yang berkembang dalam kultur nelayan yakni cenderung boros dan menghamburkan uang pasca mendapatkan hasil melaut. Oleh karena itu saving material menggunakan perhiasan emas dirasa menjadi alternatif yang efektif dalam menabung.

Simpulan kedua merujuk pada status sosial yang terepresentasi melalui gaya hidup perempuan Tambak Lorok. Pemilihan dan kepemilikan atribut fashion pada kenyataannya turut menentukan pengelompokan stratifikasi sosial dengan berdasar pada indikatorindikator yang telah ditetapkan oleh masya- rakat setempat. Representasi gaya hidup melalui gaya berpakaian memang tidak menunjukkan pengelompokan perempuan Tambak Lorok dalam stratifikasi sosial tertentu secara signifikan. Namun perilaku konsumsi aksesoris, gadget dan barang elektronik dapat menjadi indikator lain dalam menempatkan perempuan Tambak Lorok dalam kategori strata sosial rendah, tengah dan tinggi. Kepemilikan perhiasan emas menjadi indikator pertama yang dapat terindentifikasi karena terlihat secara langsung, selain itu perempuan Tambak Lorok terbiasa mengenakan perhiasan emas setelah lapisan baju dan kerudung. Selain konsumsi perhiasan emas, bentuk konsumsi gadget juga dapat dijadikan indikator dalam pengelompokkan stratifikasi dan status sosial perempuan Tambak Lorok.

Simpulan ketiga atas kajian konstruksi gaya hidup perempuan di Tambak Lorok merujuk pada status kekinian atau up to date yang tengah menjadi persoalan krusial belakangan ini khususnya bagi perempuan Tambak Lorok yang memiliki latar belakang sebagai buruh dan mahasiswa. Isu kekinian (up to date) menjadi krusial bagi kelompok perempuan Tambak Lorok tersebut menjadi wajar ketika dikaitkan dengan bentuk interaksi yang dimiliki oleh kelompok perempuan yang dimaksud. Jika dibandingkan dengan bentuk interaksi yang dimiliki oleh perempuan Tambak Lorok yang berlatarbelakang sebagai ibu rumah tangga dan pedagang di pasar, maka kelompok perempuan yang berprofesi sebagai buruh dan mahasiswa memiliki peluang interaksi dengan orang lain (orang dari luar Tambak Lorok) lebih intensif. Sehingga 
persoalan identitas dan gengsi menjadi penting dalam proses interaksi tersebut untuk menunjukkan eksistensinya. Pada konteks ini atribut-atribut gaya hidup menjadi media untuk menunjukkan status kekinian perempuan Tambak Lorok. Seperti halnya pemilihan gaya berpakaian perempuan Tambak Lorok dengan berdasar pada mode fashion terbaru. Media (baik media elektronik, cetak maupun maya/sosial) menjadi referensi utama dalam konsep berpenampilan perempuan Tambak Lorok. Mode fashion yang tengah viral di media menjadi acuan pemilihan model, gaya dan merk gaya berbusana perempuan Tambak Lorok.

Gaya hidup dan gaya berbusana yang melekat dalam diri individu tidak hanya menyangkut soal penampilan luar dari diri individu itu sendiri. Namun, gaya hidup dan gaya berbusana justru sarat akan simbol dan makna atas jati dirinya. Kajian ini menunjukkan bahwa gaya hidup pada dasarnya merupakan satu respons atas posisi individu sebagai entitas biologis yang memiliki hasrat (kebutuhan, keinginan, selera) dan posisi individu sebagai bagian dari konteks sosiokultural.[]

\section{Daftar Pustaka}

Abdullah, Irwan. 2006. Konstruksi dan Reproduksi Kebudayaan. Yogyakarta: Pustaka Pelajar.

Abdullah, Irwan. 1994. "Market, Consumption and Lifestyle Management: A Study of Yogyakarta." dalam Seminar Cultural and Social Dimension of Market Expansion, di Batam 3 Oktober 1994.
Abdullah, Irwan. 2001. Seks, Gender dan Reproduksi Kekuasaan. Yogyakarta: Tarawang Press.

Ben, Fine dan Ellen Leopold. 1993. The World of Consumption. London: Routledge.

Berger, Peter L. dan Thomas Luckman. 1990. Tafsir Sosial Atas Kenyataan. terj. H. Basari. Jakarta: LP3ES.

Bertens, Hans. 1995. The Idea of the Postmodern: A History. London: Routledge.

Chaney, David. 2011. Lifestyles: Sebuah Pengantar Komprehensif. Yogyakarta: Jalasutra.

Featherstone, Mike. 1997. "Global Culture." dalam Global Culture: Nationalism, Globalization and Modernity, a Theory, Culture and Society, ed. M. Featherstone. London: Sage Publication.

Handajani, Suzie. 2006. “Female's Sexuality in Indonesian Girls Magazines: Modern Appearance, Traditional Attitude." Antropologi Indonesia 30(1).

Hendariningrum, Retno dan M. Edy Susilo. 2008. "Fashion dan Gaya Hidup: Identitas dan Komunikasi." Jurnal Ilmu Komunikasi 6(2).

Ibrahim, Idi Subandy dan Bachruddin Ali Akhmad. 2014. Komunikasi dan Komodifikasi: Mengkaji Media dan Budaya dalam Dinamika Globalisasi. Jakarta: Yayasan Pustaka Obor Indonesia.

Koentjaraningrat. 1990. Pengantar Ilmu Antropologi. Jakarta: Rineka Cipta.

Muhamad, Indoyanu. 2016. "Indonesia Menjadi Jumlah Pengguna Internet dan Media Sosial Aktif Terbanyak di ASEAN." Sumber.Com. Retrieved October 20, 2017 (https://www.sumber.com/ 
component/k2/sumber/indonesiamenjadi-jumlah-pengguna-internet-danmedia-sosial-aktif-terbanyak-diasean.html).

Purwanti, Bela Dewi. 2013. "Gaya Hidup Masyarakat Nelayan.” Universitas Jember.

Rizqi, Rizqi, Mahendradewa Suminto dan Pitri Ermawati. 2017. "Potret Perempuan Dayak Iban, Kayan, Desa, dan Sungkung di Kalimantan Barat." Spectā: Journal of Photography, Arts, and Media 1(1):5166. Retrieved (http://journal.isi.acid/ index.php/specta/article/view/1897).

Rofhani, Rofhani. 2017. "Ekspresi dan Representasi Budaya Perempuan Muslim Kelas Menengah di Surabaya." Islamica: Jurnal Studi Keislaman 11(2): 277.
Retrieved (http://islamica.uinsby.ac.id/ index.php/islamica/article/view/326).

Rubiyanti, Eka. 1998. "Tampil Modis dengan Berjilbab: Sebuah Tren Mode Masa Kini di Yogyakarta." Universitas Gadjah Mada, Yogyakarta.

Sugiharti, Rahma. 2014. Perkembangan Masyarakat Informasi dan Teori Sosial Kontemporer. Jakarta: Kencana Prenadamedia Group.

Sumar, Andi dan K. Karman. 2014. "Perempuan Berjilbab: Dari Identitas Hingga Tren Mode Pasca Konflik di Maluku Utara." Jurnal Etnohistori 1(1). 